Int. J. Morphol.,

30(1):77-81, 2012

\title{
Location of the Mandibular Foramen According to the Amount of Dental Alveoli
}

\section{Localización del Foramen Mandibular según la Cantidad de los Alvéolos Dentales}

\author{
"Vitor Bonetti Valente; "Welton Massato Arita; "Pedro César Garcia Gonçalves; \\ *Juliana Álvares Duarte Bonini Campos; "Ticiana Sidorenko de Oliveira Capote
}

VALENTE, V. B.; ARITA, W. M.; GONÇALVES, P. C. G.; CAMPOS, J. A. D. B. \& CAPOTE, T. S. O. Location of the mandibular foramen according to the amount of dental alveoli. Int. J. Morphol., 30(1):77-81, 2012.

SUMMARY: The aim of this study was to analyze the anatomotopographic location of the mandibular foramen in the right and left ramus, and to verify the influence of the amount of dental alveoli on the foramen position. Thirty-five adult dry human mandibles of Araraquara Dental School, UNESP - São Paulo State University were assessed, with or without dental alveoli. Measurements were obtained, using a ruler and a digital caliper. The following distances were measured: FI - distance between the lowest point of the mandibular incisure and the mandibular foramen (F point); FB - distance between the mandibular base and F point; FP - distance between the posterior margin of the ramus and F point; FA - distance between the anterior margin of the ramus and F point; FT - distance between the apex of the retromolar trigone and F point. The Mann-Whitney test was used to compare each measurement according to hemi-arch, and the Kruskal-Wallis test was used to analyze the influence of the presence of alveoli on the measures. For multiple comparison, Dunn's method was used. There was no statistically significant difference in the location of the mandibular foramen when compared to the right and left hemi-arches. The amount of dental alveoli influenced, significantly, only on FA and FP distances. Thus, it was concluded that the right and left mandibular ramus showed symmetry in the location of the mandibular foramen, and the amount of alveoli influenced on the distances of the anterior and posterior margins of the mandibular ramus, in relation to the mandibular foramen.

KEY WORDS: Anatomy; Mandibular foramen; Mandibular anatomy.

\section{INTRODUCTION}

Anatomical structures such as mylohyoid sulcus, lingula of the mandible and mandibular foramen are important in dental practice and allow the professional to execute surgical and anesthetic procedures with more safety and less damages (Reitzik et al., 1976; Figún \& Garino, 1989; Minarelli \& Ramalho, 1991; Carvalho et al., 2003; Madeira, 2004).

The interest in locating the mandibular foramen dates from the beginning of local anesthesia for the desensitization of the inferior alveolar nerve that enabled the advance of anesthetic techniques (Figún \& Garino; Madeira). According to Marzola et al. (2005), the literature is scarce regarding the measurement parameters (anatomical reference points) for locating the mandibular foramen in the medial surface of the mandibular ramus, what would allow professionals to improve the anesthetic technique in the region.
With the physiological growth, the facial bones suffer a remodeling process, causing changes in the foramen position over the time (Figún \& Garino; Sicher \& Dubrull, 1991).

Minarelli (1988) concluded that the mandibular foramen is located below the occlusal plane, in a distance that decreases with the advance of age, until the bone growth is settled. According to Figún \& Garino, the mandibular foramen has the same height of the occlusal plane and, few times, in the projection of the alveolar process or above the occlusal surface of the lower molars. In children, the mandibular foramen is found in a lower position, considering the occlusal plane of the teeth. And, according to Marzola et $a l$, the foramen is a few millimeters above the occlusal plane of the lower molars, presenting anatomical variations, from one subject to another. 
According to Roberts \& Sowray (1995), there are some factors that influence the relative position of the mandibular foramen. For instance, the larger the width of the ascending ramus, the more posterior the foramen location will be.

In horizontal direction, many authors have concluded that the position of the mandibular foramen is almost in the center of the medial surface of the mandibular ramus (Sicher, 1946; Miller, 1952; Alves, 1962; Costa, 1962).

Sicher suggested that for the anesthesia of the inferior alveolar nerve, it was only needed to draw an imaginary line from 3 to $4 \mathrm{~mm}$ above the occlusal plane of the molars, introducing the anesthetic agent. Avellanal (1946), Clarke \& Holmes (1959) and Marzola (1999) asserted that the position of the mandibular foramen is $1 \mathrm{~cm}$ above the oclusal plane of the lower molars, and also at the same height of the gingival papillae of the upper teeth when the individual is with his mouth closed. However, according to Nicholson (1985) and Hetson et al. (1988), there is variability of the two mandibular rami in the same person, thus it is not possible to standardize the foramen identification.

It also should be pointed out that the need for the foramen location is not restricted to anesthetic techniques, but is also necessary for reconstructive surgery. As an example, the osteotomy of the mandibular ramus can be cited, where the location of the mandibular foramen is important to avoid injuries of the neurovascular bundle that are in the mandibular canal (Daw et al.,1988; Kaffe et al., 1994; Keros-Naglic' et al., 1997).

Thus, the aim of this study was to analyze the anatomotopographic location of the mandibular foramen of adult dry mandibles and its relation to the amount of dental alveoli in the foramen position.

\section{MATERIAL AND METHOD}

This work received the approval of the Committee of Ethics on Research from Araraquara Dental School, UNESP - São Paulo State University (protocol 07/09).

Thirty five adult dry human mandibles, partially or fully dentate, belonging to the Laboratory of Anatomy of Araraquara Dental School, UNESP, were analyzed.

The presence and amount of dental alveoli in each hemi-mandible was analyzed. Measurements were obtained, using a ruler and a digital caliper, based on the methodology of Minarelli \& Ramalho.
Measuring Points. The V-shaped depression located above the mandibular foramen, called mandibular foramen fossa by Minarelli \& Ramalho, presents clear margins and limits that converge, inferiorly, to one apex, point $\mathrm{F}$, which was considered as mandibular foramen. The following distances were measured from point F: FI - distance between the lowest point of the mandibular incisure and point F; FB - distance between the mandibular base and point F; FP - distance between the posterior margin of the mandibular ramus and point F; FA - distance between the anterior margin of the mandibular ramus and point F; FT - distance between the apex of the retromolar trigone and point $\mathrm{F}$ (Fig. 1).

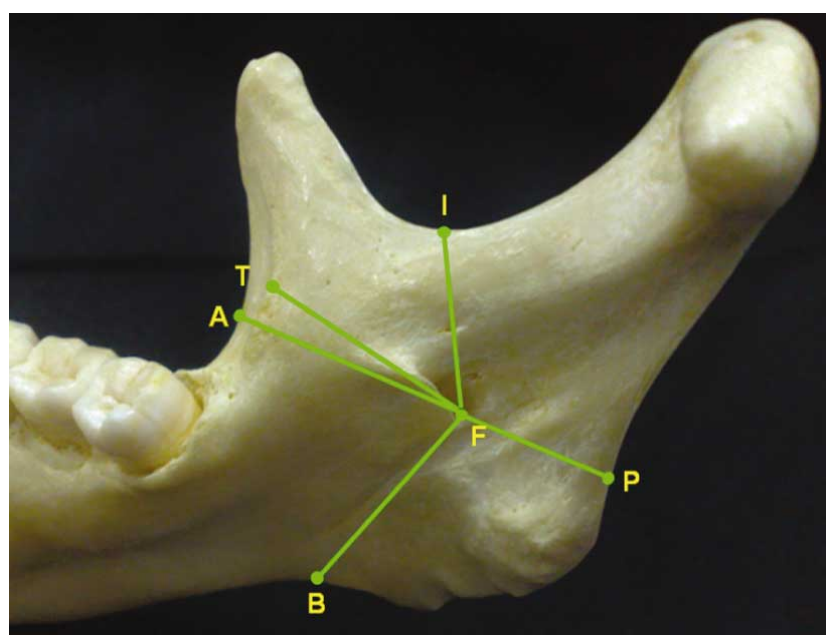

Fig. 1. Medial view of the right ramus of the mandible. Reference points for measurements.

Statistical Analysis. A descriptive statistical analysis was performed. For the comparison of each measure (FA, FP, FT, FI, FB) according to hemi-arch (R: right; L: left), the Mann Whitney test was done. For the comparison of each measure according to the presence of alveoli in the hemi-arches (G0: absence of dental alveoli; G1: presence of 1 to 4 dental alveoli; G2: presence of 5 to 8 dental alveoli) was used the KruskalWallis test and, for the multiple comparison it was used the Dunn's method. The significance level used was 5\%.

\section{RESULTS}

In Table I, it can be observed the comparison of each mandibular measure according to hemi-arch. It was observed no statistically significant difference between the location of the mandibular foramen according to hemi-arch.

Thirteen mandibular hemi-arches evaluated did not show dental alveoli, 20 showed from 1 to 4 alveoli, and 37 showed 
VALENTE, V. B.; ARITA, W. M.; GONÇALVES, P. C. G.; CAMPOS, J. A. D. B. \& CAPOTE, T. S. O. Location of the mandibular foramen according to the amount of dental alveoli. Int. J. Morphol., 30(1):77-81, 2012

from 5 to 8 alveoli. The comparison of mandibular measures according to the amount of dental alveoli is in Table II.
The amount of dental alveoli influenced, significantly, on FA and FP distances.

Table I. Comparison of each mandibular measure (FA, FP, FT, FI, FB) according to hemi-arch (R: right; L: left).

\begin{tabular}{llccccccccc}
\hline & & \multicolumn{8}{c}{ Summary Measures } \\
\cline { 3 - 11 } Measures & Side & Mean \pm SD & Min. & Q1 & Q2 & Q3 & Max. & rs* & CV(\%) & $\mathbf{p}^{* *}$ \\
\hline FA & R & $16.94 \pm 2.55$ & 12.22 & 14.97 & 17.01 & 18.67 & 21.64 & 1183.5 & 15.03 & \\
& L & $17.32 \pm 2.23$ & 13.61 & 15.76 & 17.13 & 19.17 & 21.03 & 1301.5 & 12.85 & 0.488 \\
FP & R & $14.24 \pm 2.46$ & 8.72 & 12.64 & 14.32 & 15.85 & 19.66 & 1277.5 & 17.26 & \\
& L & $14.03 \pm 2.33$ & 9.29 & 12.52 & 14.09 & 15.35 & 19 & 1207.5 & 16.61 & 0.681 \\
FT & R & $14.23 \pm 2.57$ & 10.17 & 12.45 & 13.77 & 15.89 & 20.27 & 1226.5 & 18.08 & \\
& L & $14.40 \pm 2.48$ & 10.7 & 12.98 & 13.89 & 15.08 & 23.75 & 1258.5 & 17.2 & 0.851 \\
FI & R & $24.12 \pm 3.14$ & 17.52 & 22.65 & 23.55 & 26.15 & 30.36 & 1275.5 & 13 & \\
& L & $23.65 \pm 2.74$ & 18.15 & 21.32 & 24.01 & 25.28 & 28.56 & 1209.5 & 11.58 & 0.698 \\
& RB & $39.88 \pm 4.74$ & 31.43 & 36.09 & 40.1 & 42.93 & 51.03 & 1229.5 & 11.89 & \\
& L & $40.00 \pm 5.18$ & 30.31 & 36.42 & 40.52 & 42.36 & 55.94 & 1255.5 & 12.95 & 0.879 \\
\hline
\end{tabular}

*rs: rank sum:**Mann-Whitney Test

Table II. Comparison of each mandibular measure (FA, FP, FT, FI, FB) according to the presence of alveoli in hemi-arches (G0: absence of dental alveoli; G1: presence of 1-4 dental alveoli; G2: presence of 5-8 dental alveoli).

\begin{tabular}{|c|c|c|c|c|c|c|c|c|c|c|}
\hline \multirow[b]{2}{*}{ Measures } & \multirow[b]{2}{*}{ Alveolus } & \multicolumn{8}{|c|}{ Summary Measures } & \multirow[b]{2}{*}{$\mathbf{p}^{* * *}$} \\
\hline & & Mean \pm SD & Min. & Q1 & Q2 & Q3 & Max. & rs* & CV(\%) & \\
\hline \multirow[t]{3}{*}{ FA } & $\mathrm{G}_{0}$ & $15.87 \pm 2.20$ & 12.22 & 14.70 & 15.91 & 17.81 & 20.30 & $327 a$ & 13.89 & \\
\hline & $\mathrm{G}_{1}$ & $16.48 \pm 2.01$ & 13.54 & 14.56 & 16.49 & 19.59 & 20.22 & $602^{\mathrm{a}, \mathrm{b}}$ & 12.21 & \\
\hline & $\mathrm{G}_{2}$ & $17.92 \pm 2.38$ & 13.48 & 15.99 & 18.30 & 15.48 & 21.64 & $1556 \mathrm{~b}$ & 13.28 & $0.013 * * *$ \\
\hline \multirow[t]{3}{*}{ FP } & $\mathrm{G}_{0}$ & $14.66 \pm 1.67$ & 11.53 & 14.17 & 15.15 & 14.65 & 16.68 & $528^{\mathrm{a}, \mathrm{b}}$ & 11.41 & \\
\hline & $\mathrm{G}_{1}$ & $12.88 \pm 2.02$ & 9.21 & 11.56 & 12.82 & 16.41 & 16.13 & $497.5^{\mathrm{a}}$ & 15.64 & \\
\hline & $\mathrm{G}_{2}$ & $14.63 \pm 2.56$ & 8.72 & 13.02 & 14.50 & 14.69 & 19.66 & $1459.5^{\mathrm{b}}$ & 17.50 & $0.022 * * *$ \\
\hline \multirow[t]{3}{*}{ FT } & $\mathrm{G}_{0}$ & $14.10 \pm 3.38$ & 10.27 & 12.51 & 13.53 & 15.60 & 23.75 & 402.00 & 23.98 & \\
\hline & $\mathrm{G}_{1}$ & $14.10 \pm 2.58$ & 10.17 & 11.65 & 14.08 & 15.07 & 19.72 & 702.00 & 18.28 & \\
\hline & $\mathrm{G}_{2}$ & $14.51 \pm 2.16$ & 11.65 & 13.13 & 14.02 & 26.27 & 20.27 & 1381.00 & 14.89 & 0.618 \\
\hline \multirow[t]{3}{*}{ FI } & $\mathrm{G}_{0}$ & $23.98 \pm 3.27$ & 18.15 & 22.72 & 24.73 & 24.49 & 29.18 & 491.00 & 13.63 & \\
\hline & $\mathrm{G}_{1}$ & $22.94 \pm 2.49$ & 17.52 & 21.31 & 23.35 & 27.25 & 28.32 & 581.00 & 10.84 & \\
\hline & $\mathrm{G}_{2}$ & $24.36 \pm 2.99$ & 18.58 & 22.17 & 24.19 & 42.62 & 30.36 & 1413.00 & 12.26 & 0.245 \\
\hline \multirow[t]{3}{*}{ FB } & $\mathrm{G}_{0}$ & $39.15 \pm 5.50$ & 31.43 & 35.54 & 38.87 & 41.74 & 51.03 & 419.50 & 14.04 & \\
\hline & $\mathrm{G}_{1}$ & $38.04 \pm 4.69$ & 30.31 & 34.62 & 37.09 & 43.39 & 47.72 & 566.00 & 12.33 & \\
\hline & $\mathrm{G}_{2}$ & $41.24 \pm 4.58$ & 33.49 & 38.57 & 41.48 & 7.29 & 55.94 & 1499.50 & 11.09 & 0.078 \\
\hline
\end{tabular}

*rs: rank sum; **Kruskal-Wallis Test; ***statistical significance for a=5\% a,b: Dunn's Method: identical letters indicate statistical similarity

\section{DISCUSSION}

The location of the mandibular foramen is essential for surgical planning, especially in the functional or esthetic restoration of the dentofacial deformities (Reitzik et al.; Hetson et al.; Kaffe et al.).
The measurements obtained in this study, as well as those observed by Carvalho et al., have presented a considerable variation, which demonstrates the variability in size and form of the analyzed mandibles. The different methodologies 
observed in the mandibular foramen studies should also be considered. The literature reports innumerous variations of the mandible, causing difficulties in providing references of standard measures for the professional (Marzola et al.)

The distance between the mandibular foramen and the anterior margin of the ramus ranged from 11 to $34 \mathrm{~mm}$ on the right side, and from 13 to $36 \mathrm{~mm}$ on the left side, in the study of Carvalho et al.; the distance between the foramen and mandibular incisures ranged from 11.5 to 23 on the right side, and from 11 to 21 on the left side. In the present study, the FA distance ranged from 12.22 to 21.64 on the right side, and from 13.61 to 21.03 on the left side; FI ranged from 17.52 to 30.36 on the right side, and from 23.65 to 28.56 on the left side.

In the study of Reis et al. (1977), the average value of FA was 17.65 (right side) and 18.04 (left side). For the present study, 16.94 was the average value observed of FA on the right side, and 17.32 on the left side. In both studies, the left side presented FA slightly higher values.

The average value of FP was 14.24 on the right side, and 14.03 for the left side. For FI, the average value was 24.12 (right side) and 23.65 (left side). In the study of Reis et al., lower values of FP (10.47 - right side and 10.14 - left side) and FI (15.7 - right side and 16.04 - left side) were observed.

According to Mendonza et al. (2004), the values of FI were 16.8 and $16 \mathrm{~mm}$ for the right and left side, respectively. The authors observed a higher discrepancy between the highest and lowest value. In the study of da Fontoura et al. (2002), the average value of FI was $15.8 \mathrm{~mm}$. The values of FI were higher in the present work, probably due to the standardization of the location of the mandibular foramen, which was the lowest point of the mandibular foramen fossa. da Fontoura et al. determined the site for the measurement of the mandibular foramen as a point in the posterior margin of the fossa, and Mendonza $e t$ al. determined a point located in the middle of the fossa. Besides the variability in the methodology, the different authors values related to the mandibular foramen may be due to the variation in size and form of the studied mandibles.

According to the presented results, there was symmetry in the positioning of the mandibular foramen between both sides, right and left, for all measurements taken from point $\mathrm{F}$, vertically, from the incisure to the mandibular base, as well as horizontally, from the anterior to the posterior margins of the mandible. Other authors did not find statistically significant differences between the right and left rami in the analyzed measures either (Minarelli \& Ramalho; Carvalho et al.; Marzola et al.; Ennes \& Medeiros, 2009).

The results related to the influence of dental alveoli in the location of the mandibular foramen showed that the presence, absence and amount of alveoli influence the location of the foramen in relation to the anterior and posterior margins of the mandibular ramus.

Marzola et al. verified that the average value of FA was $22 \mathrm{~mm}$, in edentulous and dentate mandibles; the FP values were $16 \mathrm{~mm}$ for dentate mandibles and 15 for the edentulous mandibles; the FB value was 21 for dentate mandibles and 20 for edentulous mandibles. According to the authors, there was no statistically significant difference between dentate and edentulous mandibles.

According to the results of this study, it was concluded that the right and left mandibular rami presented symmetry in the location of the mandibular foramen, and the amount of alveoli influenced the distances of the anterior and posterior margins of the mandibular ramus, in relation to the mandibular foramen.

VALENTE, V. B.; ARITA, W. M.; GONÇALVES, P. C. G.; CAMPOS, J.A. D. B. \& CAPOTE, T. S. O. Localización del foramen mandibular según la cantidad de los alvéolos dentales. Int. J. Morphol., 30(1):77-81, 2012.

RESUMEN: El objetivo de este trabajo fue evaluar la posición anátomo-topográfica del foramen mandibular en ambas ramas de la mandíbula y verificar la influencia de la cantidad de alvéolos dentales en la posición del foramen. Se evaluaron 35 mandíbulas humanas secas de individuos adultos de la Facultad de Odontología de Araraquara, Universidade Estadual Paulista - UNESP, con o sin alvéolos dentales. Se utilizó regla y calibrador digital para realizar las mediciones de las distancias entre: el punto más profundo de la incisura de la mandíbula y el foramen mandibular (FI); base de la mandíbula y el foramen (FB); margen posterior de la rama mandibular y el foramen mandibular (FP); margen anterior de la rama mandibular y el foramen (FA) y la distancia entre el vértice del trígono retromolar y el foramen mandibular (FT). Para la comparación de cada medida según hemiarcada se realizó el test de Mann-Whitney y para la influencia de la presencia de alvéolos en las medidas se utilizó el test de Kruskal-Wallis y para comparación múltiple el método de Dunn. No hubo diferencia estadística significativa en la localización del foramen mandibular al comparar el hemiarco mandibular derecho con el izquierdo. La cantidad de alvéolos dentales interfirió, de manera significativa, sólo en las distancias FA y FP. Se concluyó que las ramas mandibulares derecha e izquierda presentan simetría en el posicionamiento del foramen mandibular y la cantidad de alvéolos interfirió en las distancias de las márgenes anterior y posterior de la rama mandibular en relación con el foramen de la mandíbula.

PALABRAS CLAVE: Anatomía; Foramen mandibular; Anatomía mandibular. 


\section{REFERENCES}

Alves, E. Anatomia odontológica. 1. ed. Rio de Janeiro, Atheneu, 1962.

Avellanal, C. D. Cirugía odontomaxilar. Buenos Aires, Ediar, 1946.

Carvalho, P. L.; Pocobello, M. C. \& Reis, S. S. P. M. A comparison of the position of the mandibular foramen, in panoramic radiographs and dry skulls. Arq. Odontol., 39:45-52, 2003.

Clarke, J. \& Holmes, G. Local anesthesia of the mandibular molar teeth a new technique. Dent. Practit Dent. Rec., 36:321, 1959.

Costa, C. A. Odontopediatria. 2a ed. Rio de Janeiro, Científica, 1962.

da Fontoura, R. A.; Vasconcellos, H. A. \& Campos, A. E. S. Morphologic basis for the intraoral vertical ramus osteotomy: anatomic and radiographic localization of the mandibular foramen. J. Oral Maxillofac. Surg., 60:660-6, 2002.

Daw, J. L. Jr.; de La Paz, M. G.; Han, H.; Aitken, M. E. \& Patel, P. $\mathrm{K}$. The mandibular foramen: anatomic study and its relevance to the sagital ramus osteotomy. J. Craniofac. Surg., 10:475-9, 1999.

Ennes, J. P. \& Medeiros, R. M. Localization of mandibular foramen and clinical implications. Int. J. Morphol., 27:1305-11, 2009.

Figún, M. E. \& Garino, R. R. Anatomia Odontológica Funcional e Aplicada. 2a ed. São Paulo, Medicina Panamericana Editora do Brasil Ltda, 1989.

Hetson, G.; Share, J.; Frommer, J. \& Kronman, J. H. Statistical evaluation of the position of the mandibular foramen. Surg. Oral Med. Oral Pathol., 65:32-4, 1988.

Kaffe, I.; Ardekian, L.; Gelerenter, I. \& Taicher, S. Location of the mandibular foramen in panoramic radiographs. Oral Surg. Oral Med. Oral Pathol., 78:662-9, 1994.

Keros-Naglic', J.; Panduric', J. \& Buntak-Kobler, D. Some anatomical and anthropological measures of mandibular ramus in our population. Coll. Antropol., 21:203-10, 1997.

Madeira, M. C. Anatomia da Face Bases Anatomofuncionais para a Prática Odontológica. 5a ed. São Paulo, Sarvier, 2004.

Marzola, C. Anestesiologia. 3a ed. São Paulo, Pancast, 1999.

Marzola, C.; Frare, P. H. B.; Toledo Filho, J. L. \& Navarro, J. A. C. Forame da mandíbula: contribuição sobre sua localização para as técnicas anestésicas. Revista ATO, 7:235-58, 2005.

Mendonza, C. C.; Vasconcelos, B. C. E.; Sampaio, G.; Cauás, M.
\& Batista, J. E. M. Localização topográfica do forame mandibular: estudo comparativo em mandíbulas humanas secas. Rev. Cir. Traum. Buco-Maxilo-Facial, 4:137-42. 2004.

Miller, J. A. Some anatomical considerations in mandibular block anesthesia. Bull. North. Distr. Dent. Soc., 4:4-11, 1952.

Minarelli, A. M. Contribuição ao estudo do posicionamento do forame da mandíbula em função do crescimento. Estudo antropométrico em radiografias de crianças. Tese de Mestrado, Faculdade de Odontologia de Araraquara, Universidade Estadual Paulista, Araraquara, Brazil, 1988.

Minarelli, A. M. \& Ramalho, L. R. T. Estudo da localização do forame da mandíbula, através de mandíbulas maceradas de crianças. Rev. Odontol. UNESP, 20:119-27, 1991.

Nicholson, M. L. A study of the mandibular foramen in the adult human mandible. Anat. Rec., 212:110-2, 1985.

Reis, L. R.; Ferreira, S. S. \& Stahlke, H. N. Seleção de elementos anatômicos de referência do esplancnocrânio para a localização do nervo alveolar inferior, no homem. Acta Biol. Par., 6:9-20, 1977.

Reitzik, M.; Griffiths, R. R. \& Mirels, H. Surgical anatomy of the ascending ramus of the mandible. Br. J. Oral Surg., 14:150-5, 1976.

Roberts, D. H. \& Sowray, J. H. Analgesia local em Odontologia. 3 ed. São Paulo, Santos, 1995.

Sicher, H. The anatomy of mandibular anesthesia. JADA, 33:154157, 1946.

Sicher, H. \& Dubrul, E. L. Anatomia Oral de Sicher e DuBrull. 8 ed. São Paulo, Artes Médicas, 1991.

\section{Correspondence to:}

Ticiana Sidorenko de Oliveira Capote

Faculdade de Odontologia de Araraquara

UNESP

Departamento de Morfologia

Rua Humaitá, 1680 Centro

Araraquara - SP

CEP: 14801-903

BRAZIL

Telephone: 551633016518

Email: ticapote@gmail.com

Received: 30-06-2011

Accepted: 12-12-2011 